\title{
PENENTUAN KEPUTUSAN INVESTASI DENGAN MENGGUNAKAN INFORMASI AKUNTANSI DIFERENSIAL PADA CV. NYIUR TRANS KAWANUA MANADO
}

\author{
Erriana Fransiska Lembong ${ }^{1}$, Jantje Tinangon ${ }^{2,}$ Victorina Tirayoh ${ }^{3}$ \\ ${ }^{1,2,3}$ Fakultas Ekonomi dan Bisnis, Jurusan Akuntansi, Universitas Sam Ratulangi, Jl. Kampus Bahu, Manado, \\ 95115, Indonesia
}

E-mail : errianafransisca99@gmail.com

\begin{abstract}
Decision-making is one of the functions of managers. To determine investment decisions, companies need management accounting information in which there is differential accounting information, which is useful to assist companies in choosing the best alternative among alternatives available in order to generate investment decisions that benefit the company. This study aims to determine how the effectiveness of differential accounting information to choose the best alternative among the available alternatives of renting or buying fixed assets (buildings) with the calculation of investment valuation. The object of this research is a service company engaged in transportation services and goods custody, namely CV Nyiur Trans Kawanua Manado. This research is a descriptive research with qualitative approach, and using case study method. The results showed that the differential accounting information has been effectively done by the company and the company has determined the investment decision that is renting the building among the available alternatives because it is more profitable company.

Keywords: differential accounting information, determination of investment decision
\end{abstract}

\section{PENDAHULUAN}

Perusahaan jasa merupakan sebuah organisasi yang menjual produk tak berwujud, untuk mendapatkan keuntungan dari penjualan tersebut. Berbeda dengan perusahaan lainnya seperti perusahaan manufaktur maupun perusahaan dagang yang menghasilkan produk, perusahaan jasa memberikan jasa atau tenaga dari karyawan yang dijual kepada konsumen untuk memperoleh laba atau keuntungan.Untuk menjalankan kegiatan perusahaan dewasa ini, kecepatan dan ketepatan informasi sangat berpengaruh terhadap pengambilan keputusan. Kesalahan informasi akan berakibat buruk bagi sebuah keputusan begitu pun juga dengan keterlambatan informasi, akan berakibat pada terlambatnya suatu pengambilan keputusan yang tepat.

Dalam mengelolah perusahaan, manajer harus membuat keputusan yaitu dengan mempertimbangkan secara hati-hati dari berbagai alternatif tindakan dan memilih tindakan yang terbaik untuk mencapai tujuan yang direncanakan. Oleh karena itu, strategi-strategi tepat diperlukan perusahaan guna mencapai tujuan, yakni meminimalisir pengeluaran dan memaksimalkan laba. Akan tetapi, bagi perusahaan yang telah berkembang, memperluas usaha lewat investasi adalah salah satu target capaian.Informasi akuntansi dibutuhkan oleh manajemen dari berbagai jenjang organsiasi untuk menyusun rencana kegiatan perusahaan dimasa yang akan datang. Dalam pemilihan usulan investasi, manajemen memerlukan informasi akuntansi manajemen yaitu akuntansi diferensial sebagai salah satu dasar penting untuk menentukan pilihan investasi, terutama pada tahap penganalisaan konsekuensi tiap alternatif tindakan yang digunakan dalam pengambilan keputusan, sehingga memungkinkan memilih alternatif yang terbaik diantara alternatif tindakan yang tersedia dan dipertimbangkan. Namun untuk menghasilkan keputusan yang baik, perusahaan juga 
memerlukan perhitungan penilaian keputusan investasi, seperti payback period dan juga net present value yang digunakan dalam penelitian ini.

CV. Nyiur Trans Kawanua Manado merupakan cabang perusahaan dari CV Nyiur Atsiri. Nyiur Trans merupakan salah satu perusahaan penyedia jasa, yaitu jasa penyedia transportasi umum berkelas eksekutif dengan rute Manado - Kotamobagu dan sebaliknya, serta menyediakan jasa penitipan barang dengan rute yang sama. Meningkatnya pelanggan atau konsumen dari CV. Nyiur Trans Manado ini direspon oleh pihak manajemen dengan membuka gedung disetiap kota yang menjadi tujuan keberangkatan dari angkutan Nyiur Trans Manado ini. Akan tetapi, dengan membuka gedung disetiap kota, manajemen diperhadapkan dengan pengambilan keputusan menyewa atau membeli gedung sebagai aktiva tetap perusahaan. Keputusan yang diambil oleh pihak manajemen merupakan keputusan yang sangat berpengaruh bagi keuntungan perusahaan.

\section{TINJAUAN PUSTAKA}

\subsection{Akuntansi Manajemen}

Akuntansi manajemen adalah bidang akuntansi yang berfokus pada penyediaan, termasuk pada pengembangan dan penafsiran informasi bagi para manajer yang digunakan sebagai bahan perencanaan, pengendalian operasi, dan dalam pengambilan keputusan. (Samryn 2012:4). Dalam dunia usaha baik perusahaan jasa maupun manufaktur, membutuhkan informasi akuntansi sebagai alat pengawasan maupun sebagai dasar pengambilan keputusan. Dalam proses pengambilan keputusan, seorang manajer membutuhkan informasi akuntansi manajemen, karena informasi manajemen cakupannya lebih luas, tidak hanya menyangkut masalah keuangan tetapi juga non keuangan.

\subsection{Pengertian Informasi Akuntansi Manajemen}

Menurut Hansen dan Mowen (2015 : 5) Sistem informasi akuntansi manajemen menyediakan informasi yang sangat dibutuhkan untuk memenuhi tujuan - tujuan manajemen tertentu. Pada dasarnya informasi akuntansi manajemen adalah suatu sistem yang berperan serta membantu akuntansi di dalam melaksanakan transformasi data menjadi informasi, yang mana informasi tersebut berguna sebagai bahan bagi manajemen untuk pengambilan keputusan.

\subsubsection{Jenis-jenis Informasi Akuntansi Manajemen}

Sujarweni (2015:10) mengatakan jenis dari informasi akuntansi manajemen adalah sebagai berikut :

1. Informasi akuntansi penuh (Full Cost Accounting Information)

2. Informasi akuntansi differensial (Differential Accounting Information)

3. Informasi akuntansi pertanggungjawaban (Responsilbility Accounting Information).

\subsubsection{Informasi Akuntansi}

Simamora (2012:9) mengatakan bahwa Informasi Akuntansi biasanya merupakan satu-satunya sumber informasi kuantitatif yang menggabungkan hasil aktivitas semua unit perusahaan. Terdapat dua penyebab hal itu, pertama, pemeliharaan kinerja yang menguntungkan menjadi perhatian utama pihak pertama yang menanamkan dana mereka di perusahaan. Walaupun tidak selalu menjadi sasaran tunggal perusahaan, namun profitabilitas merupakan kendala penting karena tanpa profitabilitas yang memadai, maka arus dana akan mongering, dan pada akhirnya akan mengakibatkan berhentinya aktivitas perusahaan. Kedua, informasi akuntansi sangatlah penting karena menunjukkan satu-satunya cara menilai hasil berbagai aktivitas dari segi informasi yang sama. Informasi akuntansi berfungsi sebagai mekanisme integrative yang dipakai untuk mengkoordinasikan bermacam-macam aktivitas, dan sebagai suatu ukuran seluruh kinerja dan kelangsungan hidup perusahaan. 


\subsubsection{Tujuan Informasi Akuntansi}

Berdasarkan pernyataan Halim, dkk (2013:8), sistem informasi akuntansi memiliki empat tujuan dalam penyusunannya, yaitu :

1. Menyediakan informasi untuk membebankan pelayanan, produk dan berbagai macam objek yang menjadi kepentingan manajemen.

2. Menyediakan informasi untuk perencanaan, koordinasi, pengendalian, dan pengambilan keputusan.

3. Untuk memperbaiki pengendalian akuntansi dan pengecekan intern, memotivasi manajer dan karyawan lainnya untuk mencapai tujuan organisasi secara selektif.

4. Mengukur kinerja aktivitas, manajer, subunit, karyawan lainnya di dalam organisasi.

Dari tujuan dan karakteristik sistem informasi akuntansi di atas, dapat ditarik suatu kesimpulan bahwa tujuan dan karakteristik sistem informasi akuntansi berkaitan dengan kegiatan pengelolaan data transaksi keuangan dan non keuangan menjadi informasi yang dapat memenuhi kebutuhan pemakainya.

\subsubsection{Konsep Informasi Akuntansi Diferensial}

Pengertian informasi akuntansi diferensial, antara lain dikemukakan oleh Halim, dkk (2013:11) mendefinisikan informasi akuntansi diferensial memberikan informasi tentang taksiran aktiva, pendapatan, serta biaya yang berbeda apabila suatu tindakan tertentu dipilih, dibandingkan dengan alternatif tindakan yang lain."

Informasi yang relevan untuk pengambilan keputusan adalah informasi akuntansi diferensial, baik yang bersifat kuantitatif maupun non kuantitatif. Informasi akuntansi sebagai informasi yang bersifat kuantitatif sangat membantu dalam pengambilan keputusan bisnis. Pengambilan keputusan selalu menyangkut kegiatan untuk masa yang akan datang dan selalu menyangkut pilihan berbagai alternatif. Oleh karena itu, informasi yang relevan untuk pengambilan keputusan juga informasi yang mempunyai karakteristik demikian.

\subsubsection{Karakteristik Pendapatan Diferensial, Biaya Diferensial dan Laba Diferensial}

Halim, dkk (2013:103) mengatakan informasi akuntansi differensial terdiri dari beberapa bagian, yaitu :

1. Pendapatan Diferensial

Pendapatan diferensial merupakan pendapatan yang berbeda dalam suatu kondisi, dibandingkan dengan kondisi-kondisi lainnya.

2. Biaya Diferensial

Biaya differensial adalah biaya yang berbeda dalam suatu kondisi, dibandingkan dengan kondisi-kondisi yang lain". Sedangkan menurut Simamora (2012:220), biaya differensial adalah pendekatan terhadap analisis biaya relevan yang terfokus pada biaya yang berbeda dalam serangkaian alternatif.

3. Laba Diferensial

Laba diferensial adalah laba yang akan datang dan berbeda diantara berbagai alternatif yang mungkin dipilih. Besarnya laba diferensial dihitung dari perbedaan antara laba pada alternative tertentu dibandingkan dengan laba pada alternatif lainnya. Besarnya laba diferensial diperoleh dengan menggunakan rumus :

\section{Laba differensial $=$ Pendapatan differensial - Biaya Differensial}

\subsubsection{Pengertian Investasi}

Samryn (2012:368) menyatakan bahwa konsep investasi adalah salah satu aspek dari penentuan anggaran modal, selain keputusan pendanaan. Perbedaan yang mendasar diantara keduanya kalau keputusan pendanaan berfokus pada keputusan yang berhubungan dengan usaha pemenuhan kebutuhan peningkatan dana melalui pinjaman, ekuitas atau gabungan keduanya. Keputusan investasi sisi lain lebih focus pada pilihan-pilihan membeli suatu aktiva, melaksanakan suatu proyek, membuat suatu produk, dan lain sebagainya yang lebih mengarah kepada pengadaan infrastruktur untuk menunjang kegiatan operasional. 


\subsubsection{Jenis - jenis Investasi}

Mulyadi (2007 : 284) menyatakan investasi dapat dibagi menjadi empat golongan sebagai berikut :

1. Investasi uang tidak menghasilkan laba (non-profit investment).

2. Investasi yang tidak dapat diukur labanya (non-measurable provite investment).

3. Investasi dalam penggantian ekuipmen (replacement investment).

4. Investasi dalam perluasan usaha

\subsubsection{Investasi Dalam Aktiva Tetap}

Manullang dan Sinaga (2005:122) mengatakan Investasi dalam asset/ aktiva tetap diartikan sebagai proses yang mengacu pada sebuah penganggaran modal. Sebelum melakukan tindakan, proses pengambilan keputusan perusahaan harus didasari oleh keputusan yang matang, proses pengambilan keputusan berkenaan dengan investasi dalam aktiva tetap, yang memerlukan proposal diterima atau ditolak dengan investasi dalam aktiva tetap, yang memerlukan proporsional diterima atau ditolak hal ini mengacu pada penganggaran modal.

\subsubsection{Metode Penilaian Investasi}

Mulyadi (2007 : 292) mennyatakan ada beberapa metode untuk menilai perlu tidaknya suatu investasi atau memilih macam alternative investasi, yaitu sebagai berikut :

1. Payback Period

2. Average Return on Investment Method

3. Net Present Value Method

4. Discount Cash Flows Method

\subsubsection{Keputusan Investasi}

Adapun dasar keputusan investasi menurut Tandelilin (2005:20) terdiri dari :

1. Return

2. Risk

3. The time factor

\subsubsection{Pengambilan Keputusan}

Harold dan O'Donnel (2013:15) menyatakan bahwa pengambilan keputusan adalah pemilihan diantara alternatif mengenai suatu cara bertindak yaitu inti dari perencanaan, suatu rencana tidak dapat dikatakan tidak ada jika tidak ada keputusan, suatu sumber yang dapat dipercaya, petunjuk atau reputasi yang telah dibuat.

\subsubsection{Manfaat Informasi Akuntansi Diferensial Dalam Pengambilan Keputusan Investasi}

Menurut Sujarweni (2015:57) ada beberapa manfaat informasi akuntansi diferensial dalam pengambilan keputusan yang pada umumnya dihadapi oleh pihak manajemen dalam pengambilan keputusan, yaitu :

1. Membeli atau membuat sendiri

2. Menjual / memproses lebih lanjut suatu produk

3. Menghentikan atau melanjutkan produksi produk tertentu

4. Menerima/menolak pesanan khusus

\subsection{Penelitian terdahulu}

Elvhyn Novan Ananda tahun 2015 dengan judul Analisis Biaya Diferensial Untuk Pengambilan Keputusan Dalam Rencana Pengadaan Alat Berat Membeli atau Menyewa pada CV Putri Dita Tenggarong. Hasil penelitian menunjukkan bahwa pemilihan alternatif untuk membeli menggunakan kredit bank lebih menguntungkan dibandingkan menyewa dengan menggunakan sewa guna usaha.

Njo Anastasia, Sutoto Yakobus, Connie Susilawati tahun 2001 dengan judul Analisa Investasi dalam Pengambilan Keputusan Investasi pada Pengembangan Lapangan Golf dan Perumahan Citraraya. Hasil penelitian ini menunjukkan bahwa keputusan investasi yang 
diambil adalah pada alternatif pertama yaitu properti, 9-hole lapangan golf dan perumahan dalam bentuk kavling golf.

\section{Metode Penelitian}

\subsection{Jenis Penelitian}

Jenis penelitian yang digunakan adalah penelitian kualitatif dengan menggunakan pendekatan deskriptif. Penelitian ini berfokus pada penguraian data yang bersangkutan dengan situasi pada CV. Nyiur Trans Kawanua Manado secara mendalam.

\subsection{Tempat dan waktu penelitian}

Penelitian ini akan dilaksanakan pada CV.Nyiur Trans Kawanua Manado, yang beralamat di Jl.Sam Ratulangi, Wanea, Kota Manado, Sulawesi Utara. Waktu penelitian dimulai pada bulan Februari sampai waktu yang telah ditentukan.

\subsection{Prosedur Penelitian}

Prosedur penelitian yang akan dilakukan adalah :

1. Permohonan mengadakan penelitian.

2. Persiapan

3. Observasi

4. Wawancara

5. Mengolah data

6. Menarik kesimpulan penelitian dan memberi saran

\subsection{Metode Pengumpulan Data}

\subsubsection{Jenis Data}

Penelitian terbagi menjadi dua bagian yaitu sebagai berikut:

1. Data Primer

2. Data Sekunder

\subsubsection{Sumber Data}

Ada dua sumber data penelitian yang digunakan dalam penelitian ini, antara lain adalah:

1. Survei lapangan dan wawancara

2. Data yang telah dipublikasikan

\subsubsection{Teknik Pengumpulan Data}

1. Teknik Wawancara

2. Teknik Dokumentasi

3. Studi Kepustakaan

\subsection{Metode Analisis}

Metode analisis data yang digunakan adalah metode analisis deskriptif, dengan mengumpulkan kemudian menyaring keterangan-keterangan yang dibutuhkan secara detail.

\section{HASIL ANALISIS DAN PEMBAHASAN}

\subsection{Hasil Penelitian}

Hasil wawancara yang dilakukan penulis kepada pimpinan perusahaan menunjukkan bahwa informasi akuntansi yang sedang dialami oleh perusahaan adalah informasi akuntansi diferensial. Dimana perusahaan mengalami ketidakpastian dalam pemilihan alternatif akan membeli atau menyewa gedung dalam pembukaan kantor disetiap daerah tujuan armada. Dalam rencana pembukaan gedung baru atau kantor disetiap daerah tujuan, data pendapatan rata-rata per bulan dalam 2 rute perjalanan CV. Nyiur Trans Kawanua Manado yang diperoleh disajikan pada Tabel 4.1. 


\section{Tabel 4.1}

Pendapatan rata-rata per bulan dalam 2 rute perjalanan

\begin{tabular}{|c|c|c|c|c|c|c|c|c|}
\hline Rute & Unit & $\begin{array}{c}\text { Jumlah } \\
\text { Keberangkatan } \\
\text { per hari }\end{array}$ & $\begin{array}{c}\text { Kapasitas } \\
(\mathbf{p a x})\end{array}$ & $\begin{array}{c}\text { Rata-rata } \\
\text { terisi } \\
(\mathbf{p a x})\end{array}$ & $\begin{array}{c}\text { Harga } \\
\text { Tiket } \\
(\mathbf{R p})\end{array}$ & $\begin{array}{c}\text { Target } \\
(\mathbf{R p})\end{array}$ & $\begin{array}{c}\text { Jumlah } \\
\text { hari } \\
\text { dalam } \\
\text { bulan }\end{array}$ & $\begin{array}{c}\text { Total } \\
\text { per } \\
\text { bulan } \\
(\mathbf{R p})\end{array}$ \\
\hline $\mathrm{M}-\mathrm{K}$ & 1 & 3 & 11 & 8 & 100.000 & 800.000 & 30 & 72.000 .000 \\
\hline $\mathrm{K}-\mathrm{M}$ & 1 & 3 & 11 & 8 & 100.000 & 800.000 & 30 & 72.000 .000 \\
\hline $\mathrm{JP}$ & 1 & 3 & 4 & 60.000 & 240.000 & 30 & 21.600 .000 \\
\hline \multicolumn{2}{|r|}{ TOTAL } \\
\hline
\end{tabular}

\subsection{Pembahasan}

\subsubsection{Analisis Perhitungan Diferensial Membeli atau Menyewa Gedung}

Berdasarkan penelitian yang dilakukan, perhitungan antara kedua alternatif yang tersedia, yaitu membeli atau menyewa. Terkait dengan alternatif tersebut, maka perkiraan biaya yang akan dikeluarkan selama setahun untuk masing-masing alternatif adalah sebagai berikut :

1. Perkiraan Biaya jika menggunakan alternatif I (membeli gedung) dapat dilihat pada tabel 4.2 .

Tabel 4.2

Perkiraan biaya dengan menggunakan alternatif I

\begin{tabular}{|c|c|c|c|c|}
\hline No. & Keterangan & Unit & Harga & Jumlah Harga \\
\hline 1. & Investasi Awal Beli Gedung & 1 & Rp 800.000.000 & $\mathrm{Rp} 800.000 .000$ \\
\hline \multicolumn{3}{|c|}{ TOTAL } & Rp 800.000.000 & Rp 800.000.000 \\
\hline \multicolumn{5}{|c|}{ Biaya-biaya jika membeli } \\
\hline 1. & Biaya Pemeliharaan & 1 & Rp 50.000.000 & Rp 50.000.000 \\
\hline 2. & Biaya Penyusutan & 1 & Rp 160.000.000 & $\mathrm{Rp} 160.000 .000$ \\
\hline 3. & Biaya Asuransi & 1 & Rp 90.000 .000 & Rp 90.000 .000 \\
\hline 4. & Biaya Tenaga Kerja & & Rp 42.500 .000 & $\mathrm{Rp} \quad 42.500 .000$ \\
\hline & & & TOTAL & Rp 342.500.000 \\
\hline
\end{tabular}

Sumber data : CV Nyiur Trans dan data diolah

2. Perkiraan Biaya jika menggunakan Alternatif II (menyewa gedung) dapat dilihat pada tabel 4.3

Tabel 4.3

Perkiraan biaya dengan menggunakan alternatif II

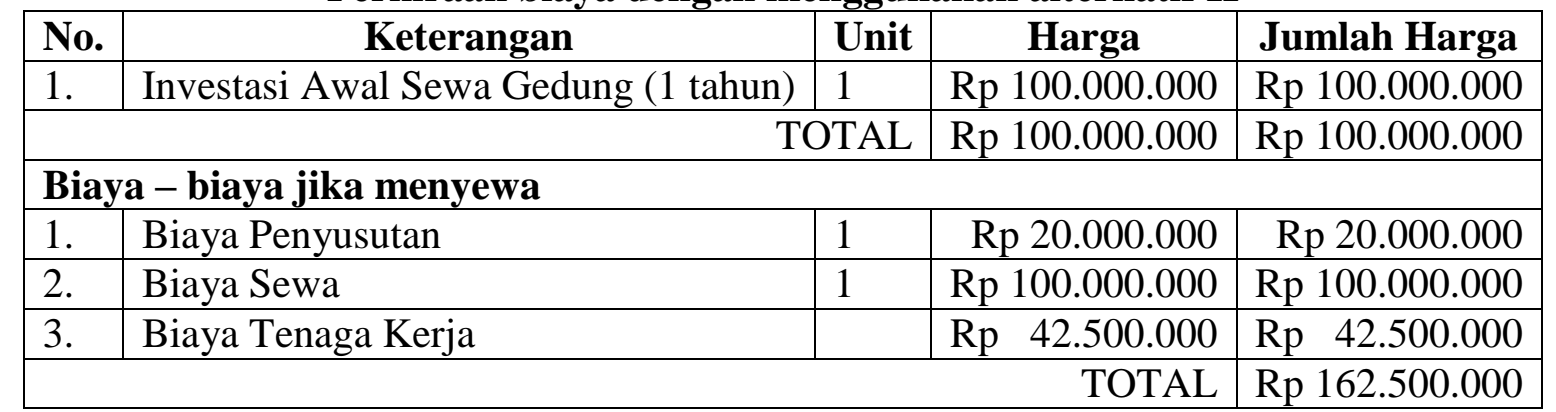

Sumber data : CV Nyiur Trans dan data diolah

3. Analisis Diferensial Membeli dan Menyewa Gedung CV Nyiur Trans Kawanua Manado dapat dilihat pada tabel 4.4 
Tabel 4.4

Analisis Diferensial Membeli dan Menyewa Gedung

\begin{tabular}{|c|c|c|}
\hline Pendapatan & Rp 1.987.200.000 & Rp 1.987.200.000 \\
\hline Keterangan & Beli & Sewa \\
\hline Biaya Gedung & $\mathrm{Rp} 800.000 .000$ & Rp 100.000.000 \\
\hline Biaya Penyusutan & Rp 160.000.000 & Rp 20.000 .000 \\
\hline Biaya Asuransi & $\mathrm{Rp} \quad 90.000 .000$ & - \\
\hline Biaya Pemeliharaan & Rp $\quad 50.000 .000$ & - \\
\hline Total Biaya & Rp 1.010.000.000 & $\begin{array}{ll}\text { Rp } & 120.000 .000 \\
\end{array}$ \\
\hline Laba Diferensial & $\begin{array}{ll}\mathbf{R p} & \mathbf{9 7 7 . 2 0 0 . 0 0 0} \\
\end{array}$ & Rp 1.867.200.000 \\
\hline
\end{tabular}

Dapat dilihat dari tabel di atas bahwa alternatif menyewa gedung lebih menguntungkan perusahaan karena selain mengeluarkan biaya yang lebih sedikit, perusahaan juga mendapatkan laba yang lebih besar jika menyewa gedung.

\subsubsection{Perhitungan Menggunakan Penilaian Investasi}

Namun untuk lebih melihat manakah alternatif terbaik dalam pengambilan keputusan investasi ini, perlu dilakukan perhitungan dengan menggunakan perhitungan penilaian investasi dengan beberapa metode yang telah dijelaskan pada seksi tinjauan pustaka. Dan dalam penelitian ini penulis akan menggunakan dua metode penilaian investasi untuk lebih menguji manakah alternatif terbaik yang seharusnya diambil oleh perusahaan, yaitu dengan menggunakan perhitungan Pay-back Period dan Net Present Value.

a. Perhitungan Penilaian Investasi Menggunakan Payback Period

1. Pay-back Period Alternatif I (Membeli)

$\begin{aligned} \text { Pay-back Period } & =\frac{\text { Investasi }}{\text { Laba tunai rata-rata }} \times 12 \text { bulan } \\ & =\frac{\text { Rp. } 1.000 .000 .000}{\text { Rp. } 977.200 .000} \times 12 \text { bulan }\end{aligned}$

$=12.2$ bulan (dibulatkan 1 tahun)

\section{Pay-back Period Alternatif I (Menyewa)}

$$
\begin{aligned}
\text { Pay-back Period } & =\frac{\text { Investasi }}{\text { Laba tunai rata-rata }} \times 12 \text { bulan } \\
& =\frac{\text { Rp. } 1.000 .000 .000}{\text { Rp. } 1.867 .200 .000 .000} \times 12 \text { bulan } \\
& =6.5 \text { bulan (dibulatkan 7 bulan) }
\end{aligned}
$$

Dari perhitungan pay-back periodpada kedua alternatif di atas, diketahui bahwa jika perusahaan memilih alternatif I yaitu membeli gedung, maka lama pengembalian investasi adalah selama 1 tahun. Sedangkan jika perusahaan memilih alternatif II yaitu menyewa gedung, lama pengembalian investasi adalah selama 7 bulan. Selisih waktu dari kedua alternatif tersebut adalah 5 bulan. Maka perusahaan sebaiknya memilih alternatif II yaitu menyewa gedung. 
b. Perhitungan Penilaian Investasi Menggunakan Net Present Value (NPV)

1. NPV pada alternatif I (Membeli) dapat dilihat pada tabel 4.5

Tabel 4.5

NPV pada alternatif I

\begin{tabular}{|c|c|c|c|}
\hline Tahun & Cash Inflow & D.F 20\% & PV Cash Inflow \\
\hline 1 & 977.200 .000 & 0,833 & 814.007 .600 \\
\hline 2 & 977.200 .000 & 0,695 & 679.154 .000 \\
\hline 3 & 977.200 .000 & 0,578 & 564.821 .600 \\
\hline \multicolumn{3}{|c|}{ TOTAL } & 2.057 .983 .200 \\
\hline
\end{tabular}

NPV = Present Value Cash Inflow - Present Value Investment

$=\operatorname{Rp} 2.057 .983 .200-1.000 .000 .000$

$=$ Rp 1.057.983.200

Sumber data : CV Nyiur Trans Kawanua dan data diolah

2. NPV pada alternatif II (Menyewa) dapat dilihat pada tabel 4.6

Tabel 4.6

NPV pada alternatif II

\begin{tabular}{|c|c|c|c|}
\hline Tahun & Cash Inflow & D.F 20\% & PV Cash Inflow \\
\hline 1 & 1.867 .200 .000 & 0,833 & 1.555 .377 .600 \\
\hline 2 & 1.867 .200 .000 & 0,695 & 1.297 .704 .000 \\
\hline 3 & 1.867 .200 .000 & 0,578 & 1.079 .241 .600 \\
\hline \multicolumn{3}{|c|}{ TOTAL } & 3.932 .323 .200 \\
\hline
\end{tabular}

NPV = Present Value Cash Inflow - Present Value Investment

$=\operatorname{Rp} 3.932 .323 .200-1.000 .000 .000$

= Rp 2.932.323.200

Sumber data : CV Nyiur Trans Kawanua dan data diolah

Dengan menggunakan perhitungan metode NPV diatas, dapat diketahui bahwa jumlah NPV dari alternatif I adalah sebesar $\mathrm{Rp}$ 1.057.983.200 dan alternatif II sebesar 2.932.323.200. Sesuai dengan teori mengenai NPV, maka kedua alternatif tersebut dapat diterima karena mempunyai jumlah NPV $>0$. Namun jumlah NPV terbesar adalah alternatif II yaitu menyewa, jadi perusahaan lebih menguntungkan jika memilihh alternatif tersebut.Discount factor merupakan tingkat diskonto yang telah ditetapkan oleh perusahaan yaitu sebesar $20 \%$ yang digunakan dalam perhitungan penilaian investasi menggunakan metode NPV ini.

\subsubsection{Penerapan Informasi Akuntansi Diferensial Dalam Pengambilan Keputusan Investasi Pada CV Nyiur Trans Kawanua}

Informasi akuntansi manajemen khususnya akuntansi diferensial sangat diperlukan di CV Nyiur Trans Kawanua Manado khususnya untuk membantu pihak internal di dalam pengambilan keputusan investasi. Karena informasi akuntansi diferensial ini menyangkut masa yang akan datang yang digunakan untuk pengambilan keputusan dan juga bermanfaat untuk memastikan setiap bagian perusahaan berfungsi dengan efektifitas yang maksimal.

\section{KESIMPULAN DAN SARAN}

\subsection{Kesimpulan}

Berdasarkan analisa dan evaluasi yang dilakukan penulis, maka dapat ditarik kesimpulan bahwa informasi akuntansi diferensial dalam pengambilan keputusan investasi asset tetap yang didukung dengan perhitungan penilaian investasi sudah efektif dilakukan 
dalam pengambilan keputusan pada CV Nyiur Trans Kawanua Manado. Hal tersebut dapat dilihat dengan alasan sebagai berikut :

1. CV Nyiur Trans Kawanua menyadari penuh akan pentingnya informasi akuntansi diferensial yang akan membantu pengambilan keputusan, baik itu keputusan jangka panjang, jangka pendek, keputusan rutin maupun untuk tujuan pengendalian intern perusahaan.

2. Berdasarkan informasi akuntansi diferensial dan perhitungan penilaian investasi, CV Nyiur Trans Kawanua Manado dapat mengambil keputusan yang baik diantara alternatifalternatif yang tersedia yaitu memilih menyewa gedung untuk kegiatan perusahaan.

\subsection{Saran}

Saran penulis bagi perusahaan adalah agar lebih berhati-hati dalam menentukan keputusan investasi, karena akan berdampak sangat besar bagi kegiatan perusahaan. Penulis juga menyarankan agar perusahaan lebih mempelajari tentang informasi-informasi akuntansi manajemen dan perhitungan penilian investasi agar dalam menentukan keputusan dilain waktu perusahaan sudah dapat memilih keputusan dengan baik. Pimpinan perusahaan juga sebaiknya memperhatikan pembagian tugas dan tanggung jawab masing-masing bagian agar dapat bekerja dengan baik sesuai bidangnya dan tidak terjadi rangkap tugas demi kelangsungan kegiatan perusahaan yang baik pada CV. Nyiur Trans Kawanua Manado.

\section{DAFTAR PUSTAKA}

Ananda, Elvhyn. 2015. Analisis Biaya Differensial Untuk Pengambilan Keputusan Dalam Rencana Pengadaan Alat Berat Membeli atau Menyewa pada CV Putri Dita Tenggarong.eJournal Administrasi Bisnis Volume 3, Nomor 3.FISIPUNMUL.http://ejournal.adbisnis.fisip-unmul.ac.id.Diakses 2015, hal 531-545.

Halim, Abdul, Bambang, Supomo, Kusufi, Syam Muhammad. 2013. Akuntansi Manajemen. Edisi ke-2.BPFE.Yogyakarta.

Hansen dan Mowen. 2015. Managerial Accounting. Salemba Empat, Jakarta.

Koontz, Harold., O Donnel, Cyril. 2013. Manajemen Dasar. Edisi Revisi, Cetakan Ke Tujuh. Bumi Aksara, Jakarta.

Manullang, Sinaga. 2005. Pengantar Manajemen Keuangan. Edisi 1. Andi Publisher. Jakarta Mulyadi. 2007. Akuntansi Manajemen: Konsep, Manfaat, dan Rekayasa, Edisi ke-3.Salemba Empat: Jakarta

Njo, Sutoto dan Connie.2001.Analisa Investasi dalam Pengambilan Keputusan Investasi pada Pengembangan Lapangan Golf dan Perumahan Citraraya.Jurnal Manajemen dan Kewirausahaan Vol 3, No 1.Universitas Kristen Petra. Surabaya. http://puslit2.petra.ac.id/ejournal/index.php/man/article/view/15606/15598.DiaksesMar et2001.

Samryn, L.M. 2012.Akuntansi Manajemen. Edisi Pertama. Kencana, Jakarta

Simamora, Henry,.(2012). Akuntansi Manajemen. Edisi III. Penerbit Star Gate Publisher. Riau

Sujarweni, V.Wiratna. 2015. Akuntansi Manajemen Teori dan Aplikasi.Pustaka Baru Press. Yogyakarta. 